\title{
Element Finite Analysis (FEA) of the resistance to shearing and compression stress of the dental crown executed out of three types of ceramic cemented with three systems adhesive cement
}

\author{
Studiu prin metoda element finit (MEF) privind rezistenţa la \\ tensiunea de forfecare şi compresiune a coroanei de acoperire executate \\ din trei tipuri de ceramică cimentate cu trei tipuri de ciment adeziv
}

Otilia Chirca, Cornelia Bîcleşanu, Dan Stoia, Anamaria Florescu, Alexandru Burcea

Facultatea de Medicină Dentară, Universitatea „Titu Maiorescu“, Bucureşti, România

\begin{abstract}
The purpose. The aim of the present study is the Finite Element Analysis (FEA) of a reconstruction model of a molar restored with an entirely ceramic crown, using 3 types of ceramic cemented with 3 different types of adhesive systems in order to identify equivalent stress and shearing values, as well as the deformations in accordance with the direction of the applied stress.

Material and method. The geometric model used in FEA is based on one reconstructed from CT scans. Following the CT scan of the dental images and their processing, the structure of an intact molar was made, which was later modified to only select the area of the crown and dental trunk. The FEA analysis aimed to identify both the values of equivalent stress and shear, as well as the deformations of the structure in accordance with the defined materials and the direction of the applied stress. In the present simulation, a single stress value of $170 \mathrm{~N}$ was chosen, but applied in sequence at 6 angles: $0^{\circ}, 30^{\circ}, 45^{\circ}, 60^{\circ}, 75^{\circ}, 90^{\circ}$. This way the shearing effects are discreetly simulated up to pure compression of the structure.

Results and discussions. The stress peaks for both the crown and the cement appear at the level of the horizontal walls, following a sudden decrease of the values recorded on the vertical walls. The change of sign at the level of the shearing stress is normal and is due to the change in orientation of the applied force in relation to the plane in which the stress is studied. Regarding cements, the equivalent stresses indicate that it is possible to reach values that can lead to the appearance of fissures on the dental interface.

Conclusions. The values of the mechanical resistances of the 3 ceramics exceed the values of the equivalent and shearing stresses analysed by at least one order of magnitude. Therefore, the application of a similar stress value cannot produce mechanical fractures on any of the ceramics, but fissures can occur in the cement or dentin.
\end{abstract}

Keywords: all-ceramic crown, finite element, shearing stress, equivalent stress

\begin{abstract}
REZUMAT
Scop. Studiul de faţă și-a propus analiza cu element finit (FEA) a unui model de reconstrucţie a unui molar restaurat cu o coroană total ceramică, utilizând 3 tipuri de ceramică cimentate cu trei sisteme adezive diferite pentru identificarea valorilor de tensiune echivalentă și de forfecare, precum şi a deformaţiilor apărute în conformitate cu direcţia de solicitare aplicată.

Material şi metodă. Modelul geometric folosit în FEA are la bază un model reconstruit din imagini scanate CT. În urma scanării CT a imaginilor dentare şi a procesării acestora, a fost realizată structura unui molar integru, care, ulterior, a fost modificată cu un plan pentru a selecta doar zona de coroană şi de colet dentar. Prin analiza FEA, s-a urmărit atât identificarea valorilor de tensiune echivalentă și de forfecare, cât și a deformațiilor structurii în conformitate cu materialele definite şi cu direcţia solicitării aplicate. În simularea de faţă, s-a ales o singură valoare de solicitare, de $170 \mathrm{~N}$, dar aplicată, pe rând, după 6 direcţii, $0^{\circ}, 30^{\circ}, 45^{\circ}, 60^{\circ}, 75^{\circ}, 90^{\circ}$. În acest fel, sunt simulate în mod discret efectele de forfecare și până la compresiune pură a structurii.

Rezultate şi discuții. Vârfurile de tensiune atât din coroană, cât și din ciment apar la nivelul pereţilor orizontali, urmând o coborâre bruscă a valorilor înregistrate pe pereţii verticali. Schimbarea de semn la nivelul tensiunilor de
\end{abstract}


forfecare este normală şi se datorează schimbării de orientare a forţei aplicate în relaţie cu planul în care este studiată tensiunea. În privinţa cimenturilor, tensiunile echivalente indică posibilă atingerea unor valori care pot conduce spre generarea de fisuri la interfaţă.

Concluzii. Valorile de rezistență mecanică ale celor 3 ceramice depășesc cu cel puțin un ordin de mărime valorile de tensiune echivalente sau de forfecare analizate. Așadar, aplicarea unei solicitări de valoare similară nu poate produce efecte mecanice de fracturare a niciuneia dintre ceramici, dar pot apărea fisuri în ciment sau dentină.

Cuvinte cheie: coroană total ceramică, element finit, tensiune de forfecare, tensiune echivalentă

\section{INTRODUCERE}

Materialele dentare sunt în prezent subiectul unor reglementări şi directive speciale în aproape toate ţările din lume, cu intenţia de a garanta eficienţa, siguranţa şi calitatea lor şi de a avea certitudinea că numai materialele biocompatibile sunt comercializate pe piaţă. Progresele tehnologice în ceramica dentară reprezintă o zonă rapidă şi în creștere în cercetarea şi dezvoltarea medicinei dentare. Aspectul estetic al restaurărilor ceramice este atribuit texturii suprafeţei restaurării, care este determinată de finisarea suprafeței, longevitatea este determinată de proprietăţile fizice ale ceramicii, iar biocompatibilitatea este dată de calităţile sale compoziţionale şi funcţionale [1].

În prezent, coroanele ceramice se fabrică prin presare la cald şi prin tehnica de proiectare asistată de computer și fabricare asistată de computer (computer-aided design and computer-assisted manufacturing) sau CAD-CAM. Ceramica IPS E. max CAD-On (Ivoclar Vivadent) este o sticlăceramică de litiu disilicat pentru aplicaţiile CADCAM. Fiind realizate prin tehnologia CAD-CAM, coroanele realizate din acest material au parametrii controlaţi, în acest fel îşi păstrează toate proprietăţile. Ceramica IPS E.max CAD-On are o duritate $5800 \mathrm{MPa}$, rezistenţă la încovoiere $360-440 \mathrm{MPa}$, iar la fractură 2,8-3,5 MPa. Coeficientul de expansiune termică la $100-500^{\circ} \mathrm{C}$ este de 10,5 [2]. Performanţa mecanică ridicată a acestui material se datorează unei distribuţii stratificate a cristalelor disilicat de litiu alungite, ceea ce împiedică propagarea fisurilor pe planuri.

Ceramica IPS e.max Press, Ivoclar Vivadent este sticla ceramică litiu disilicat destinată tehnicii de prelucrare prin presare. Materialul prezintă o înaltă rezistenţă mecanică cu valori similare variantei CAD-CAM şi opţiuni de cimentare adezivă, autoadezivă sau convenţională în funcţie de indicaţie cu utilizarea protocoalelor de cimentare autoadezive sau convenţionale. Microstructura IPS e.max Press conţine disilicat de litiu 65\% vol, care se prezintă sub formă de cristale cu lungime ce variază între 3 şi $6 \mu \mathrm{m}$, încorporate într-o matrice de sticlă, cu o porozitate de 1 vol\% [3], care prezintă rezistenţa la flexiune $350 \mathrm{MPa}$, rezistența la fractura 3,3 $\mathrm{MPa}$.

Zirconia Novodent GS este un material ceramic cu o rezistenţă mecanică foarte bună. Din punct de vedere chimic, el este compus din elementul rar Zirconium şi oxigen. Este foarte rezistent la forţele masticatorii şi uzură. Un avantaj foarte important al zirconiei este lipsa coroziunii în timp. Este termoizolant, aşa că variaţiile de temperatură nu sunt transmise pulpei dentare, scăzând astfel riscul de apariţie a unei eventuale inflamaţii pulpare pe viitor. Fiind un material biocompatibil şi bioinert, el este foarte bine acceptat de către organism şi riscul de apariţiei reacţiilor alergice la el nu există. Zirconia are o rezistenţă la flexie cuprinsă între 800 şi $1200 \mathrm{MPa}$ şi o rezistenţă la fractură cuprinsă între 6 și $8 \mathrm{MPa}$ [4].

Rezistenţa la flexie şi la fractură a zirconiului este de 2,5 ori mai mare decât sticla ceramică cu disilicat de litiu, ceea ce sugerează că zirconia este mult mai potrivită pentru aplicaţii independente de rezistenţă la stres, cum ar fi proteze parţiale fixe cu unităţi multiple sau de lungă durată.

Succesul restaurărilor total ceramice depinde şi de modul în care se face cimentarea acestora. Tehnica de cimentare adezivă la stucturile dentare poate determina realizarea unei structuri rezistente la acţiunea forţelor masticatorii şi anihilarea fracturilor, dar şi a unei bune adaptări marginale [5].

Introducerea cimenturilor autoadezive a redus numărul necesar de etape clinice în secvenţa procedurii adezive, reducând astfel timpul de lucru. Cimentul autoadeziv este cea mai bună alegere pentru cimentarea substraturilor pe bază de zirconiu [6].

Capacitatea de polimerizare dublă (fotopolimerizare și polimerizare chimică) a multor dintre cimenturile adezive mai noi a făcut posibilă pătrun- 
derea lor în zone în care pătrunderea luminii pe suprafaţa demineralizată cu acizi este limitată sau nu poate fi atinsă [7].

Prin prezenţa particulelor de silice, ceramica disilicat de litiu este o ceramică sensibilă la acid, astfel încât ea prezintă o rezistenţă ridicată a aderenţei la structura dentară, prin mecanisme de legare micromecanică şi chimică. Interconectarea micromecanică între ceramică și cimentul adeziv se bazează pe crearea de microretenţii de suprafaţă, prin gravarea acidă cu acid fluorhidric 5\% timp de $20 \mathrm{sec}$. sau tratamente fizice cum ar fi silanizarea/ sablarea cu particule de oxid de aluminiu.

Recent, s-a arătat că utilizarea silanului combinat cu un monomer fosfat funcţional, 10-metacrililoxidecil-dihidrogen-fosfat (10-MDP), produce un mediu acid care îmbunătăţește rezistenţa adeziunii la ceramic disilicat de litiu [8-9].

Ca urmare a absenţei oricărei matrice sticloase, zirconia nu conţine silice și, în consecinţă, nu poate fi condiţionată cu tehnici convenţionale de gravare acidă. Tratamentul său constă în tratarea suprafețelelor de zirconiu prin sablare ușoară, folosind particule de alumină de $110 \mathrm{~mm}$ la $0,2 \mathrm{MPa}$.

Acest studiu analizează, cu ajutorul metodei elementului finit (MEF), un model de reconstrucţie a unui molar restaurat cu o coroană total ceramică, utilizând 3 tipuri de ceramică (IPS E.max CAD-On, Ivoclar Vivadent (crm1), Ceramica IPS E.max Press, Ivoclar Vivadent (crm2), zirconia Novodent GS (crm3) şi cimentate cu trei sisteme adezive (autogravant (Maxcem Elite, Kerr), universal (RelyX Ultimate Clicker, 3M Espe) şi cu priză dublă (Variolink Esthetic LC Ivoclar Vivadent), în vederea stabilirii rezistenţei sale la acţiunea tensiunilor de forfecare şi echivalente.

\section{MATERIAL ŞI METODĂ}

Metoda elementului finit (MEF) este folosită ca metodă de analiză a distribuţiei solicitărilor în geometrii complexe divizate în elemente utilizate ca funcţii matematice.

\section{Construcția modelului geometric}

Modelul geometric utilizat în analiza cu element finit se bazează pe un model reconstruit din imagini scanate CT. Acest set de operaţii care conduc de la un model fizic real la un model virtual 3D se subscriu ingineriei inverse. Modelele realizate în acest mod se bucură de precizia dimensională şi de formă a structurii iniţiale, cu respectarea celor mai mici particularităţi geometrice [10-12].

În acest fel, după procesarea imaginilor dentare rezultate la scanarea $\mathrm{CT}$, s-a realizat structura unui molar integru (fig. 1), care, mai apoi, a fost trunchiat cu un plan pentru a selecta doar zona de coroană şi colet dentar.

Scopul acestei operaţii a fost reducerea zonei radiculare care nu interesează în mod special în viitoarea analiză cu element finit, aceasta multiplicând doar modelul de calcul, fără a aduce o influenţă esenţială la nivelul tipurilor de preparaţii care se vor studia.

Utilizând modelul de bază, s-a realizat un model funcţional denumit în continuare coroană totală. În vederea realizării ansamblului, s-au modelat geometric și suprafeţele care joacă rol de cimenturi adezive, pentru a putea, mai apoi, atribui acestora proprietăţile mecanice corespunzătoare.

Modelarea coroanei totale este prezentată în figura 2. Aceasta a fost prelucrată interior pentru a se conjuga cu forma prelucrată a dentinei. Suprafețele care simulează frezarea dintelui au fost con-

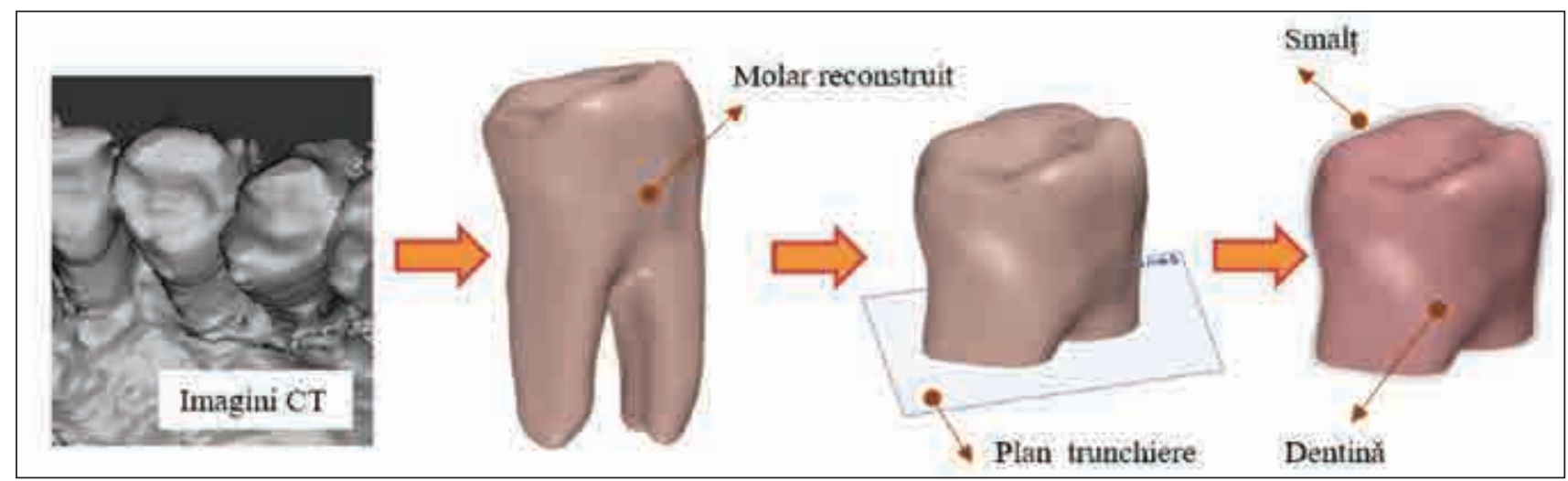

FIGURA 1. Etapele obținerii modelului geometric de bază 


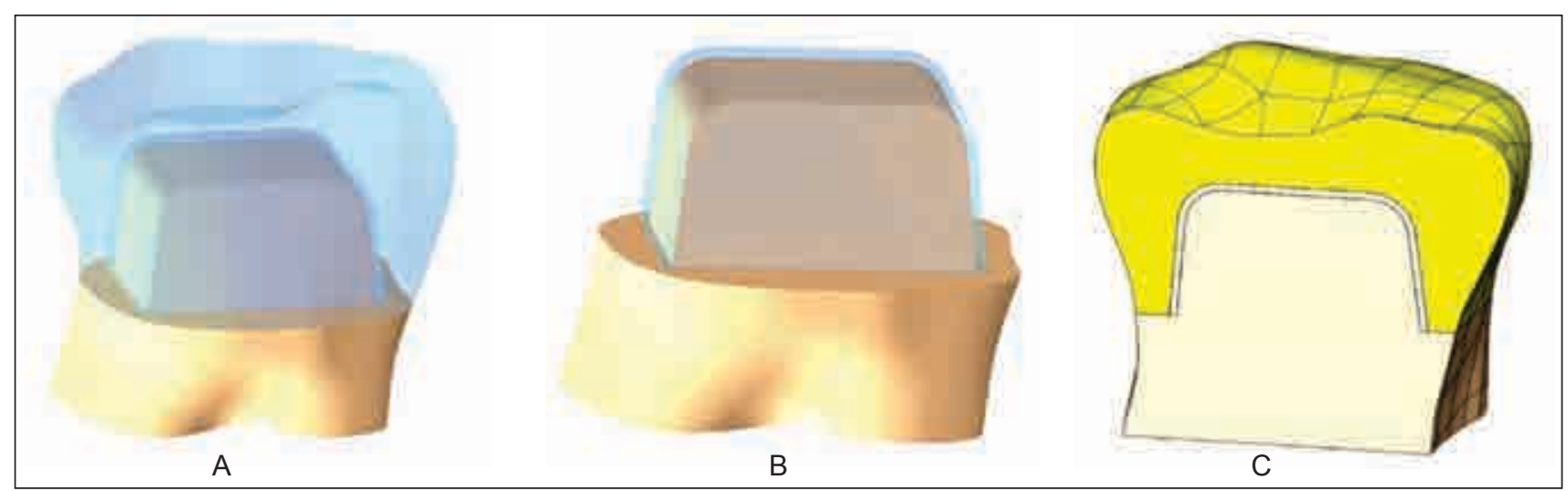

FIGURA 2. Etapele realizării modelului geometric al restaurației cu coroană totală. A. Dentină şi ciment; B. coroană ceramică; C. Ansamblu coroană totală

struite astfel încât să nu permită rotaţia coroanei pe dintele rămas, chiar şi în lipsa adezivului. Muchiile orificiului prismatic interior au fost rotunjite, pe de-o parte pentru a simula situaţia reală în care nu se pot realiza pereţi perfect drepţi sau unghiuri drepte, iar pe de altă parte pentru a preveni apariţia concentratorilor de tensiune.

În figura $2 \mathrm{C}$ se poate observa o secţiune realizată prin ansamblul final, unde se pot observa toate cele 3 componente individuale aflate în contact reciproc.

\section{Analiza cu element finit}

Metoda elementului finit (MEF) s-a realizat în Ansys 2019, pentru fiecare dintre cele 3 modele funcţionale în parte. Acestea au fost importate în program, după care s-au stabilit parametrii de analiză: materialele corespunzătoare fiecărei structuri; contactele dintre componente; solicitările şi zonele fixe; discretizarea, rezultatele de interes [13-17].

\section{Definirea materialelor în analiză}

Analiza elastică a tensiunilor şi deformaţiilor la nivelul structurilor dentare prezentate anterior utilizează proprietăţile de elasticitate (modulul longitudinal de elasticitate sau modulul de elasticitate la încovoiere, respectiv coeficientul lui Poisson) ale materialelor, conform tabelelor 1 și 2 . Acești parametri s-au selectat din literatură, pe baza încercărilor experimentale fie a producătorilor de ceramice şi cimenturi, fie a cercetătorilor independenţi [18-22].

\section{Definirea conditiilor pe contur}

Condiţiile pe contur materializează solicitările şi imobilizările pe care le prezintă structura supusă analizei MEF. Cele două condiţii sunt deosebit de importante deoarece, cu ajutorul lor, software-ul, utilizând ecuaţia elementară, va calcula în prima fază tensiunile din fiecare nod, pentru ca, mai apoi, să determine deformaţiile corespunzătoare. În si-

TABEL 1. Tipul de restaurare şi materialele utilizate

\begin{tabular}{|c|c|c|c|c|c|}
\hline Preparația & Cimentul & Cod 1 & Ceramica & $\operatorname{Cod} 2$ & \begin{tabular}{|l} 
Tip restaurare/ \\
incrustație
\end{tabular} \\
\hline Pr. I & $\begin{array}{ll}\text { Adeziv - } \\
\mathrm{R}\end{array}$ & $\operatorname{cim} I$ & $\begin{array}{l}\text { Presată - IPS E.max } \\
\text { Press,IvoclarVivadent }\end{array}$ & $\mathrm{crm} \mathrm{I}$ & coroană \\
\hline Pr. II & $\begin{array}{l}\text { Autoadeziv - } \\
\text { Maxcem }\end{array}$ & cim II & $\begin{array}{l}\text { Carbonat - IPS E.max } \\
\text { CAD-On, IvoclarVivadent }\end{array}$ & $\mathrm{crm} \mathrm{II}$ & coroană \\
\hline Pr. III & $\begin{array}{l}\text { Fotopolimerizabil - } \\
\text { Variolink }\end{array}$ & cim III & $\begin{array}{l}\text { Oxid de zirconiu - } \\
\text { ZirconiaNovodent GS }\end{array}$ & $\mathrm{crm} I I I$ & coroană \\
\hline
\end{tabular}

TABEL 2. Proprietățile mecanice asociate materialelor utilizate

\begin{tabular}{|l|c|c|c|c|}
\hline \multicolumn{1}{|c|}{ Material } & Structura & $\begin{array}{c}\text { Densitate } \\
{\left[\mathrm{kg} / \mathrm{m}^{3}\right]}\end{array}$ & $\begin{array}{c}\text { Modulul lui Young/modulul } \\
\text { în încovoiere [MPa] }\end{array}$ & $\begin{array}{c}\text { Coeficientul lui } \\
\text { Poisson [-] }\end{array}$ \\
\hline $\mathrm{crm} \mathrm{I}$ & Coroană & 2.480 & 82.300 & 0,22 \\
\hline $\mathrm{crm} \mathrm{II}$ & Coroană & 2.480 & 82.300 & 0,23 \\
\hline $\mathrm{crm} \mathrm{III}$ & Coroană & 2.480 & 88.000 & 0,34 \\
\hline $\mathrm{cim}$ I & ciment adeziv & 2.400 & 7.700 & 0,24 \\
\hline $\mathrm{cim}$ II & ciment adeziv & 2.350 & 4.400 & 0,24 \\
\hline cim III & ciment adeziv & 2.400 & 8.100 & 0,25 \\
\hline Den & Den & 2.000 & 17.000 & 0,30 \\
\hline Smalţ dentar & Smalţ & 2.750 & 74.000 & 0,23 \\
\hline
\end{tabular}


mularea de faţă, s-a ales o singură valoare de solicitare de 170 N, dar aplicată pe rând după 6 direcţii. În acest fel, sunt simulate în mod discret efectele de forfecare și până la compresiune pură a structurii (fig. 3). Orientarea de $0^{\circ}$ corespunde unei forţe de $170 \mathrm{~N}$ orizontale care produce efecte de forfecare maxime asupra celor 3 tipuri de structură. Avem apoi situaţiile intermediare de solicitare la $30^{\circ}, 45^{\circ}, 60^{\circ}, 75^{\circ}$, unde apare efectul combinat al forfecării și compresiunii, pentru ca, în ultima poziţie, $90^{\circ}$, direcţia forţei să genereze doar compresiune pură. Fixarea structurii s-a realizat la nivelul planului de trunchiere a modelului iniţial.

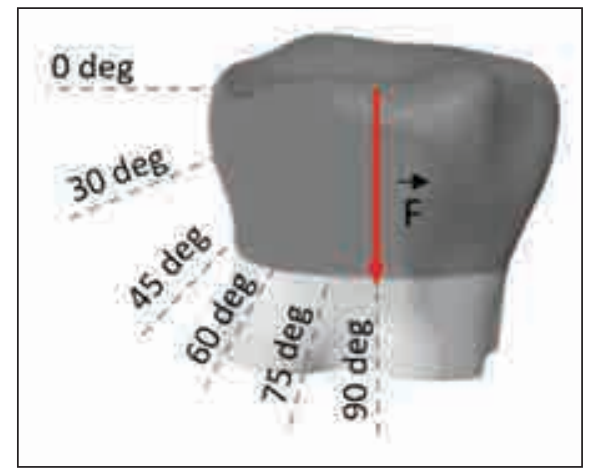

FIGURA 3. Direcții de aplicarea solicitării mecanice pe modelul funcțional

\section{Stabilirea contactelor dintre componente}

Contactele s-au stabilit manual în mod diferenţiat între suprafețele componentelor specifice reconstrucţiei. Asigurarea unei suprafeţe de contact reale ca dimensiuni și poziţie este foarte importantă deoarece aceasta dictează în mod direct felul în care solicitarea şi deformaţia se vor transmite de la un element al modelului la celălalt (fig. 4).

\section{Discretizarea structurii}

Discretizarea structurii (fig. 5) s-a realizat în mod automat folosind elemente tetraedrice de tip 10. În urma acestei operaţii, modelul a fost împărţit în structuri discrete cu următoarele caracteristici: noduri $=14.515$ şi elemente $=7.674$.

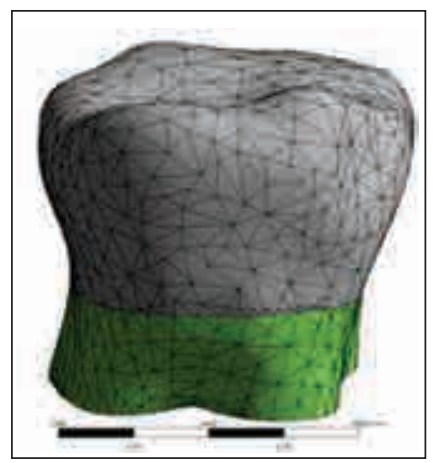

FIGURA 5. Discretizarea modelului de analiză cu elemente Tetra10

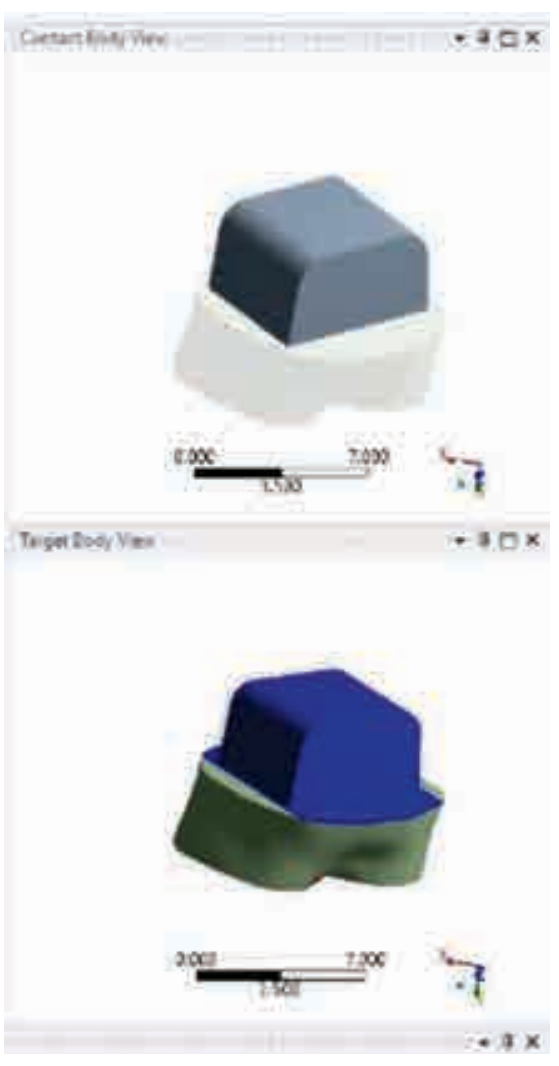

A
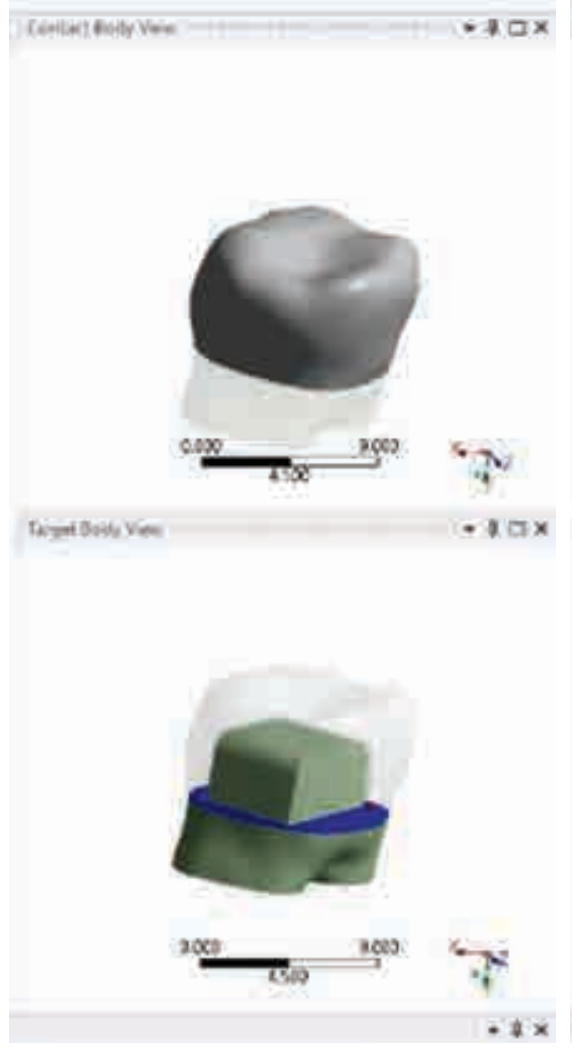

B
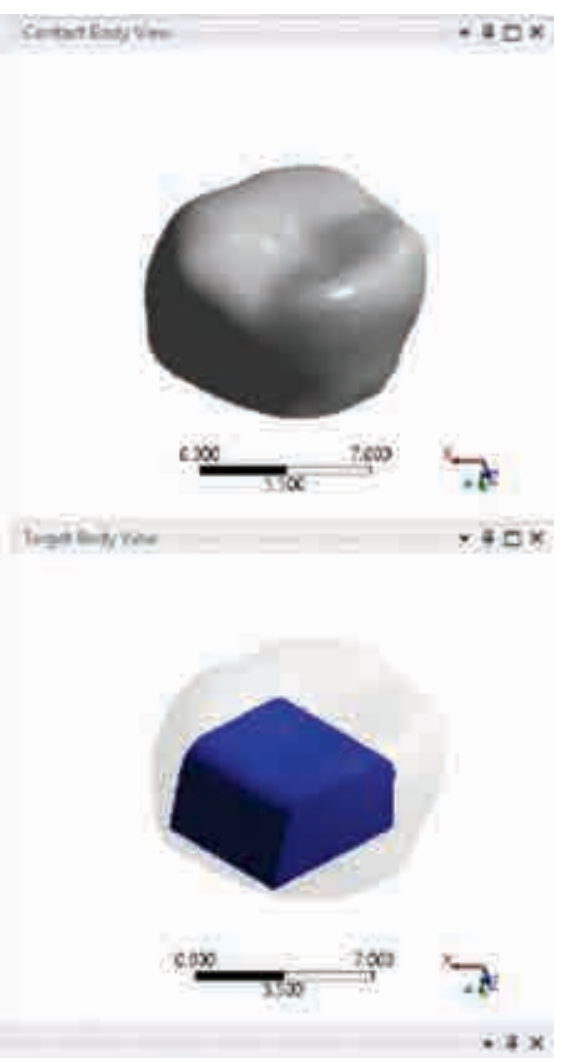

C

FIGURA 4. Contactele componentelor individuale. A. Dentină-ciment; B. Dentină-coroană; C. Coroană-ciment 




FIGURA 6. Nodurile de prelevare ale tensiunilor

\section{Punctele de prelevare ale tensiunilor}

Simularea prin MEF arată valorile de deformaţie și deplasare în toate nodurile structurii discrete, sub formă de hărţi colorate. Pentru a avea o mai bună interpretare a rezultatelor, s-au extras o serie de tensiuni din puncte speciale ale structurii, după cum urmează: tensiunile din zona mediană a ceramicii, dar şi tensiunile din zona mediană a cimentului adeziv. Harta care expune aceste zone de prelevare ale tensiunilor se prezintă împreună cu coordonatele în planul XoY în figura 6. Conform acestora, se vor prezenta în cele ce urmează valorile de tensiune sub formă tabelară și grafică.

\section{REZULTATE}

Datorită simetriei acestui tip de construcţie, modul în care tensiunile sunt distribuite capătă un aspect simetric, în strânsă legătură cu geometria. Astfel, în figurile 7 și 8 , se pot vedea zonele extin-



$0^{\circ}$

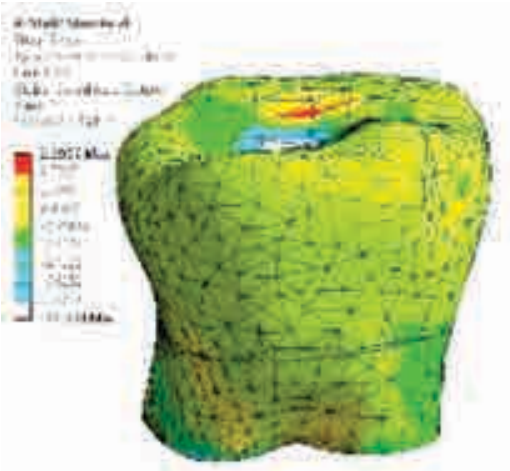

$60^{\circ}$

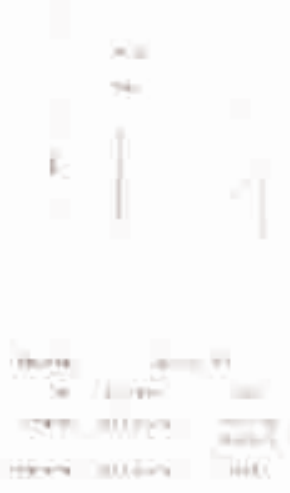

$30^{\circ}$

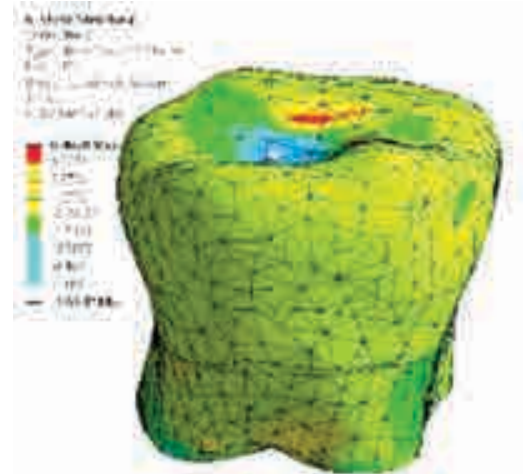

$75^{\circ}$

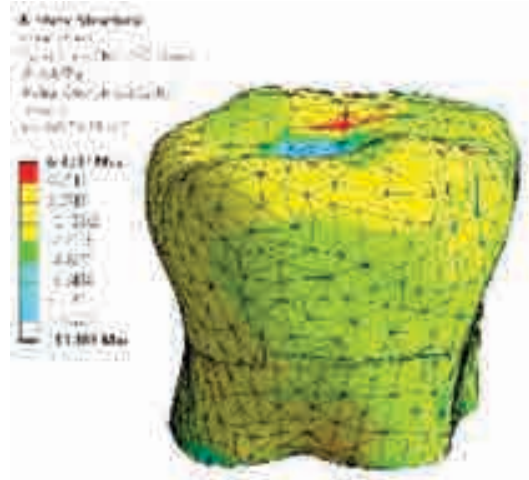

$45^{\circ}$

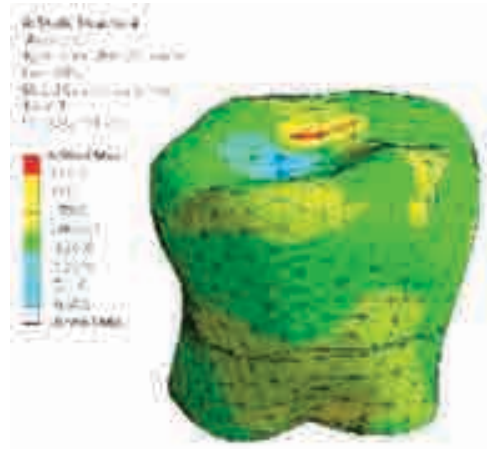

$90^{\circ}$

FIGURA 7. Tensiunea de forfecare în XY pentru solicitarea de $170 \mathrm{~N}$ şi orientările $0^{\circ}-90^{\circ}-$ Aspect exterior 


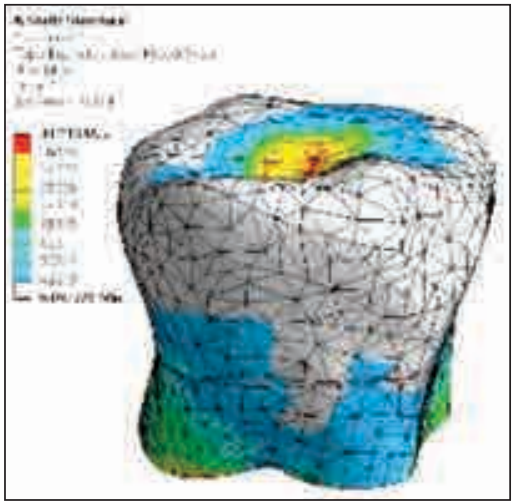

$0^{\circ}$

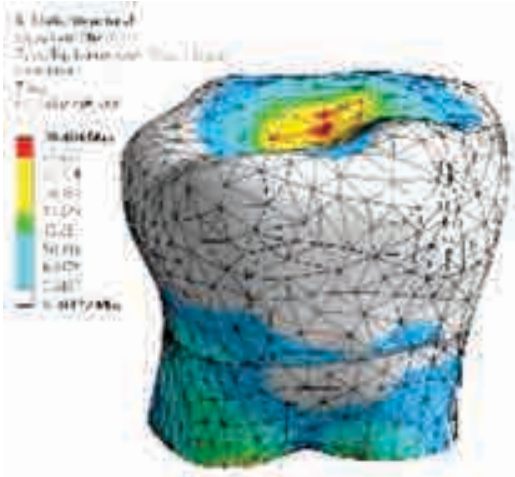

$60^{\circ}$

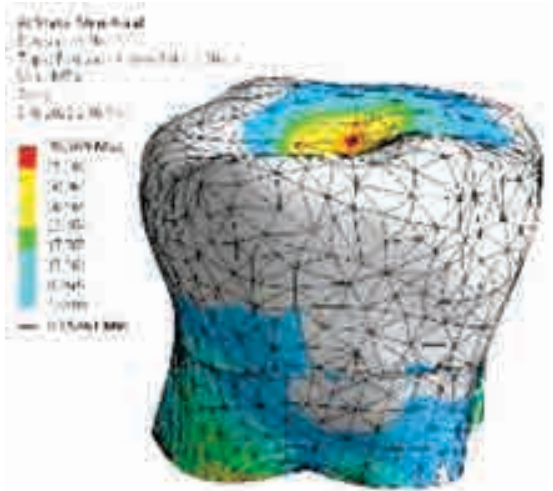

$30^{\circ}$



$75^{\circ}$

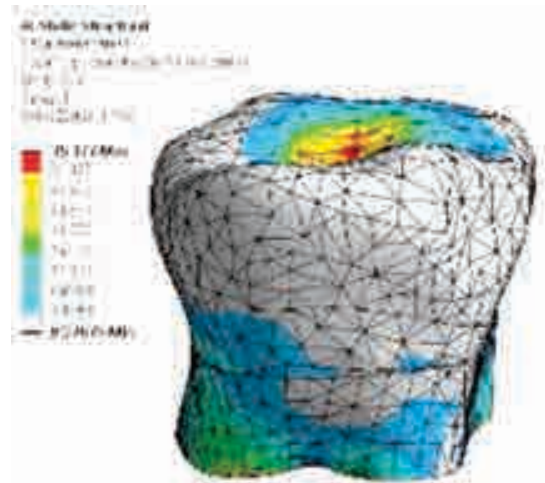

$45^{\circ}$

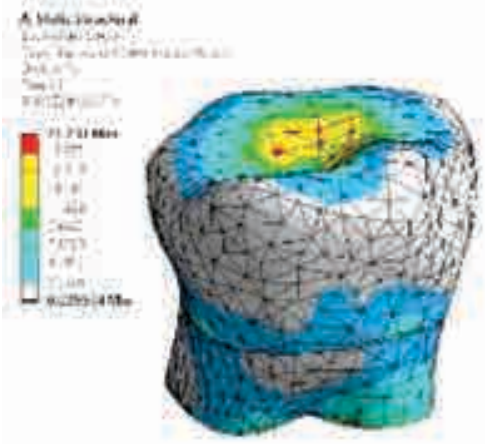

$90^{\circ}$

FIGURA 8. Tensiunea echivalentă pentru solicitarea de $170 \mathrm{~N}$ şi orientările $0^{\circ}-90^{\circ}-$ Aspect exterior

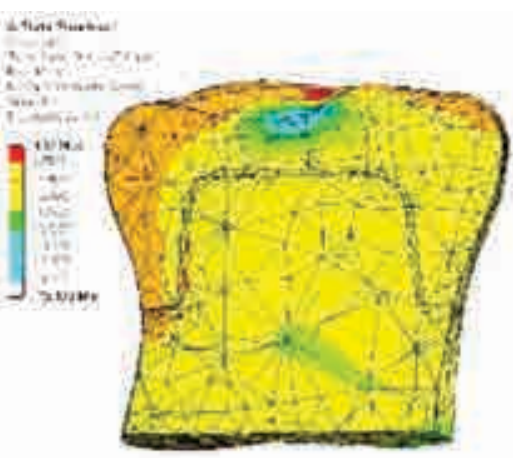

$0^{\circ}$



$60^{\circ}$

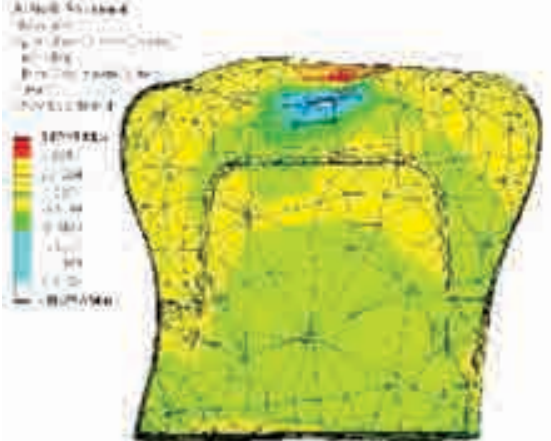

$30^{\circ}$

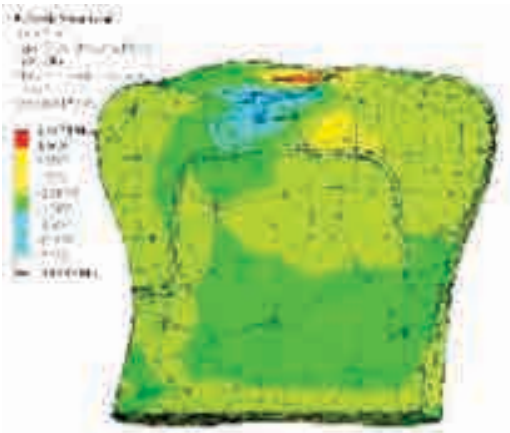

$75^{\circ}$

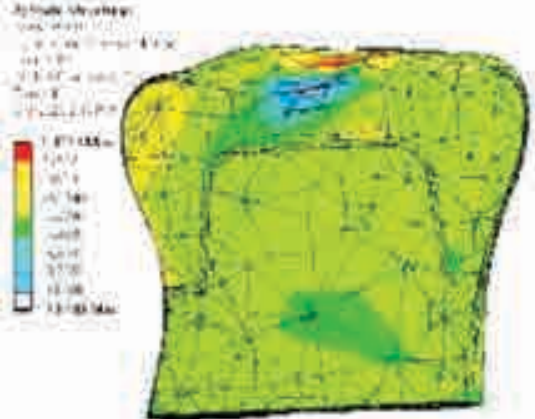

$45^{\circ}$

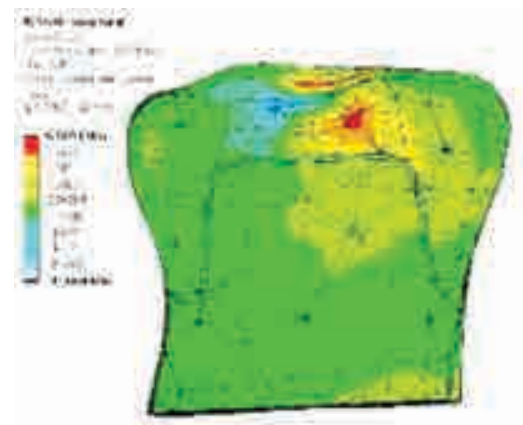

$90^{\circ}$

FIGURA 9. Tensiunea de forfecare pentru solicitarea de $170 \mathrm{~N}$ şi orientările $0^{\circ}-90^{\circ}$ - secțiune longitudinală

se ale tensiunilor din suprafaţa coroanei pentru aceeaşi suprafaţă de aplicare a forţei. Acest aspect este benefic din punct de vedere mecanic, deoare- ce realizează o dispersare a solicitării, reducând astfel șansele unei concentrări care să producă fisurare. 


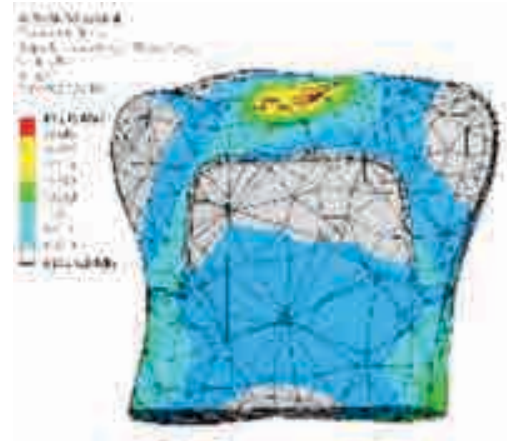

$0^{\circ}$

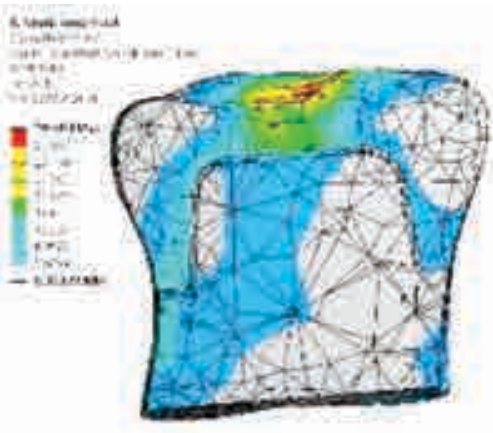

$60^{\circ}$
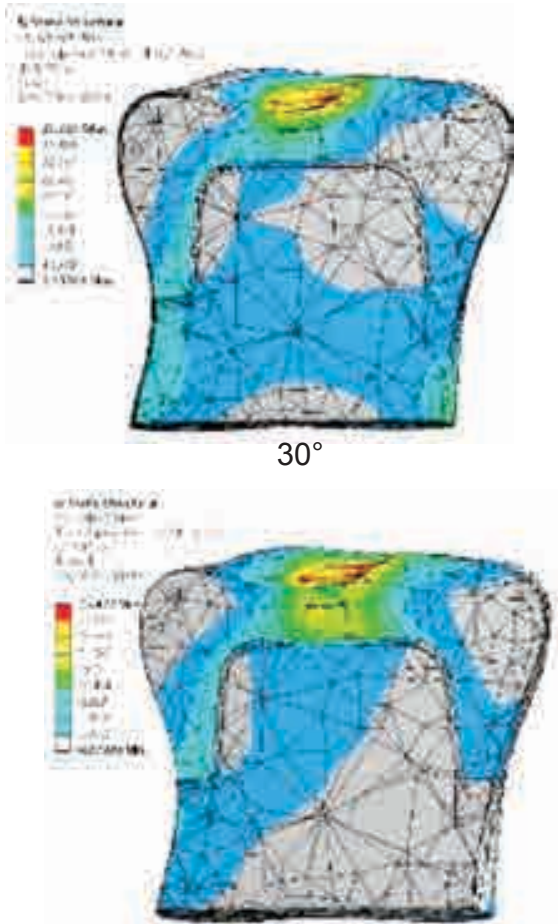

$75^{\circ}$

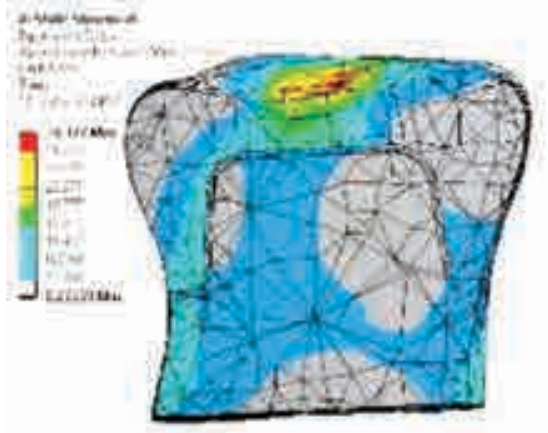

$45^{\circ}$

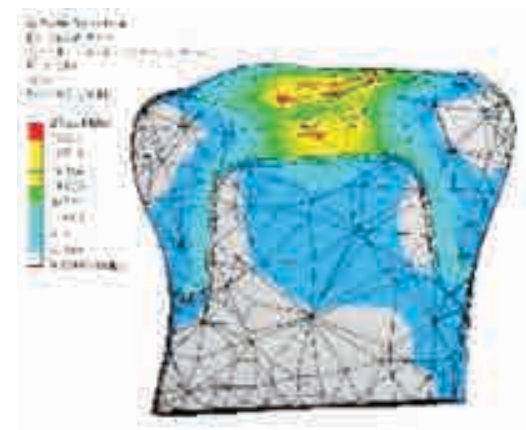

$90^{\circ}$

FIGURA 10. Tensiunea echivalentă pentru solicitarea de $170 \mathrm{~N}$ şi orientările $0^{\circ}-90^{\circ}-$ secțiune longitudinală

Secţiunile longitudinale ale ansamblului prezintă distribuţia de tensiune pe suprafețe extinse și în interiorul structurii (fig. 9 şi 10). Nu apar zone preferenţiale spre un singur perete al molarului, ci în aceeași măsură, simetric, tensiunea se transmite spre ambii pereţi (în planul studiat) şi, desigur, şi pe ceilalţi corespunzători unui plan medial. Izolarea faţă de tensiune a zonelor de cuspizi se datorează faptului că încărcarea s-a produs în axa molarului și nu pe aceștia.

În tabelele 3 şi 4 , sunt prezentate valorile numerice ale tensiunilor în nodurile de prelevare, corespunzător direcţiilor forţelor de aplicare a forţei. Pe baza acestora, s-au ridicat graficele de variaţie ale tensiunii în raport cu nodul considerat.

TABEL 3. Valorile tensiunilor din coroană

\begin{tabular}{|c|c|c|c|c|c|c|c|c|}
\hline \multirow{2}{*}{ Nr. } & \multicolumn{6}{|c|}{ Orientare } & \multirow{2}{*}{$\begin{array}{l}\text { Media } \\
{[\mathrm{MPa}]}\end{array}$} & \multirow{2}{*}{$\begin{array}{l}\text { Dev. } \\
\text { Std. }\end{array}$} \\
\hline & $0^{\circ}$ & $30^{\circ}$ & $45^{\circ}$ & $60^{\circ}$ & $75^{\circ}$ & $90^{\circ}$ & & \\
\hline 1 & 10,98 & 10,95 & 9,88 & 8,28 & 6,77 & 4,64 & 8,58 & 2,53 \\
\hline 2 & 9,27 & 9,31 & 9,22 & 8,08 & 6,21 & 4,91 & 7,84 & 1,86 \\
\hline 3 & 7,93 & 8,53 & 8,47 & 6,98 & 5,61 & 4,80 & 7,05 & 1,56 \\
\hline 4 & 7,00 & 7,42 & 8,66 & 6,75 & 5,62 & 4,98 & 6,74 & 1,31 \\
\hline 5 & 7,40 & 6,90 & 8,88 & 6,80 & 6,09 & 4,90 & 6,83 & 1,33 \\
\hline 6 & 7,27 & 6,88 & 8,99 & 12 & 0,00 & 4,38 & 58 & 1,54 \\
\hline 7 & 9,53 & 8,16 & 9,11 & 6,58 & 5,91 & 5,92 & 7,53 & 1,61 \\
\hline 8 & 11,42 & 9,63 & 12,48 & 8,54 & 7,82 & 12,66 & 10,42 & 2,06 \\
\hline 9 & 13,15 & 17,38 & 17,69 & 13,03 & 11,91 & 16,92 & 15,01 & 2,59 \\
\hline 10 & 15,15 & 22,58 & 18,59 & 18,28 & 16,58 & 16,23 & 17,90 & 2,63 \\
\hline 11 & 12,63 & 18,89 & 15,11 & 18,68 & 17,59 & 15,83 & 16,46 & 2,4 \\
\hline
\end{tabular}

\begin{tabular}{|c|c|c|c|c|c|c|c|c|}
\hline \multirow{2}{*}{ Nr. } & \multicolumn{6}{|c|}{ Orientare } & \multirow{2}{*}{$\begin{array}{l}\text { Media } \\
{[\mathrm{MPa}]}\end{array}$} & \multirow{2}{*}{$\begin{array}{l}\text { Dev. } \\
\text { Std. }\end{array}$} \\
\hline & $0^{\circ}$ & $30^{\circ}$ & $45^{\circ}$ & $60^{\circ}$ & $75^{\circ}$ & $90^{\circ}$ & & \\
\hline 12 & 9,14 & 10,00 & 9,86 & 15,75 & 16,48 & 10,06 & 11,88 & 3,30 \\
\hline 13 & 8,52 & 6,86 & 5,63 & 12,72 & 14,60 & 7,02 & 9,23 & 3,60 \\
\hline 14 & 6,11 & 3,57 & 3,17 & 9,72 & 11,58 & 4,82 & 6,50 & 3,43 \\
\hline 15 & 6,68 & 3,96 & 3,16 & 6,09 & 8,96 & 4,47 & 5,55 & 2,13 \\
\hline 16 & 5,82 & 3,33 & 3,03 & 4,10 & 5,64 & 4,99 & 4,48 & 1,18 \\
\hline 17 & 5,43 & 3,66 & 2,68 & 3,73 & 4,79 & 4,65 & 4,16 & 0,99 \\
\hline 18 & 5,92 & 3,98 & 2,89 & 3,25 & 4,40 & 4,51 & 4,16 & 1,07 \\
\hline
\end{tabular}

TABEL 4. Valorile tensiunilor din cimentul adeziv

\begin{tabular}{|c|c|c|c|c|c|c|c|c|}
\hline \multirow{2}{*}{ Nr. } & \multicolumn{6}{|c|}{ Orientare } & \multirow{2}{*}{$\begin{array}{l}\text { Media } \\
\text { [MPa] }\end{array}$} & \multirow{2}{*}{$\begin{array}{l}\text { Dev. } \\
\text { Std. }\end{array}$} \\
\hline & $0^{\circ}$ & $30^{\circ}$ & $45^{\circ}$ & $60^{\circ}$ & $75^{\circ}$ & $90^{\circ}$ & & \\
\hline 1 & 1,00 & 6,69 & 6,21 & 5,48 & 4,71 & 3,51 & 1,84 & 4,74 \\
\hline 2 & 2,00 & 4,90 & 4,33 & 4,04 & 3,39 & 3,30 & 1,64 & 3,60 \\
\hline 3 & 3,00 & 4,42 & 4,17 & 3,84 & 3,07 & 2,56 & 1,81 & 3,31 \\
\hline 4 & 4,00 & 3,95 & 3,95 & 3,71 & 3,14 & 2,64 & 2,02 & 3,23 \\
\hline 5 & 5,00 & 3,87 & 3,78 & 3,68 & 3,14 & 2,66 & 2,30 & 3,24 \\
\hline 6 & 6,00 & 3,76 & 5,50 & 3,97 & 3,23 & 4,30 & 2,80 & 3,93 \\
\hline 7 & 7,00 & 3,58 & 3,96 & 3,99 & 3,79 & 3,02 & 3,73 & 3,68 \\
\hline 8 & 8,00 & 4,07 & 10,46 & 10,32 & 9,37 & 3,42 & 5,69 & 7,22 \\
\hline 9 & 9,00 & 9,42 & 5,76 & 7,07 & 5,73 & 4,36 & 7,62 & 6,66 \\
\hline 10 & 10,00 & 5,17 & 11,02 & 11,26 & 11,65 & 6,68 & 8,23 & 9,00 \\
\hline 11 & 11,00 & 5,20 & 9,39 & 11,50 & 12,84 & 11,83 & 6,41 & 9,53 \\
\hline 12 & 12,00 & 4,78 & 8,93 & 9,96 & 12,84 & 12,62 & 4,92 & 9,01 \\
\hline 13 & 13,00 & 3,50 & 8,41 & 3,66 & 10,28 & 14,88 & 3,69 & 7,40 \\
\hline 14 & 14,00 & 4,04 & 2,96 & 4,76 & 4,05 & 10,93 & 3,07 & 4,97 \\
\hline 15 & 15,00 & 4,13 & 2,95 & 1,46 & 2,71 & 7,57 & 2,60 & 3,57 \\
\hline 16 & 16,00 & 4,22 & 1,57 & 3,15 & 1,82 & 3,28 & 2,11 & 2,69 \\
\hline 17 & 17,00 & 2,86 & 3,77 & 1,24 & 1,60 & 2,40 & 1,99 & 2,31 \\
\hline 18 & 18,00 & 2,86 & 3,40 & 1,41 & 1,33 & 2,11 & 2,07 & 2,19 \\
\hline
\end{tabular}


Deformaţiile semnificative ale structurii s-au produs la nivelul cimentului adeziv şi dentinei (fig. 11 și 12). În conformitate cu direcţia solicitării, pereţii molarului se vor deforma în mod egal la soli- citări de compresiune $\left(90^{\circ}\right)$ și nesimetric pentru solicitări oblice. $\mathrm{Nu}$ se constată deformaţii elastice semnificative ca urmare a rigidităţii mari a coroanei.

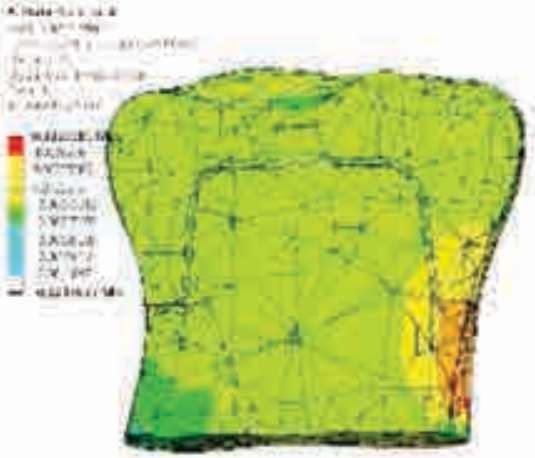

$0^{\circ}$

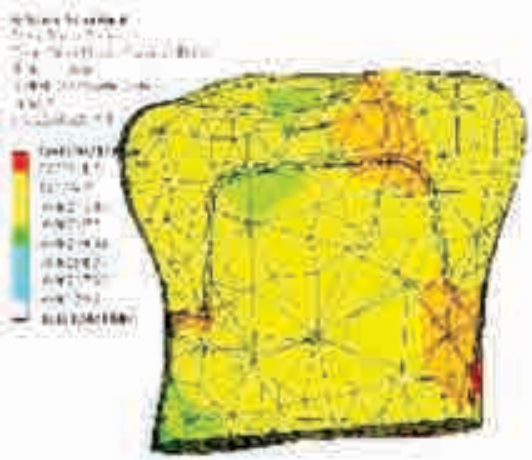

$60^{\circ}$

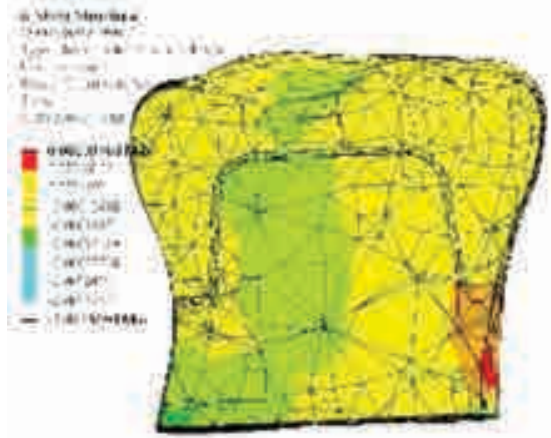

$30^{\circ}$

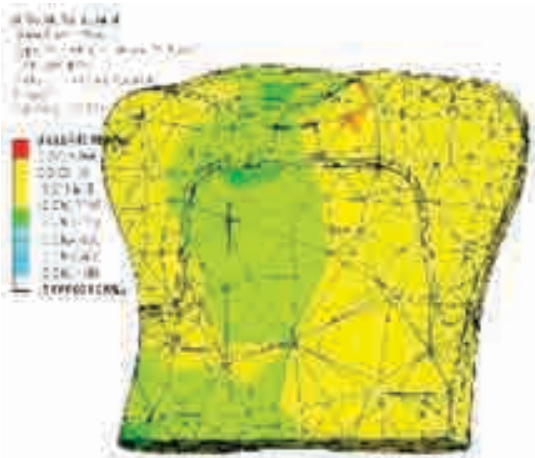

$75^{\circ}$



$45^{\circ}$

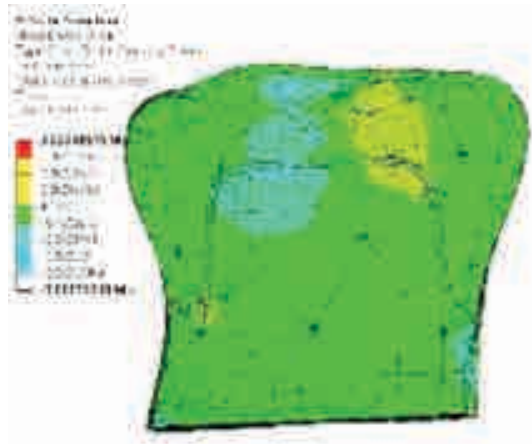

$90^{\circ}$

FIGURA 11. Deformația la forfecare pentru solicitarea de $170 \mathrm{~N}$ şi orientările $0^{\circ}-90^{\circ}$ - secțiune longitudinală



$0^{\circ}$

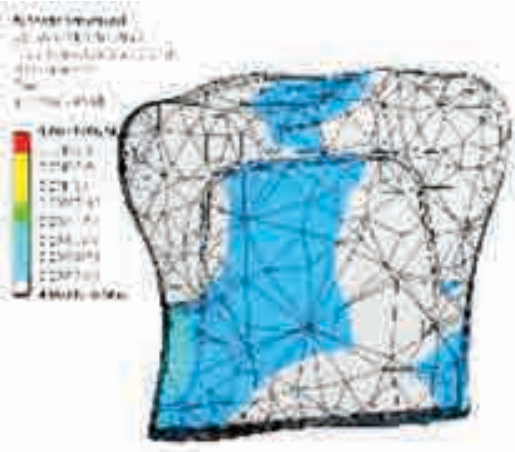

$60^{\circ}$

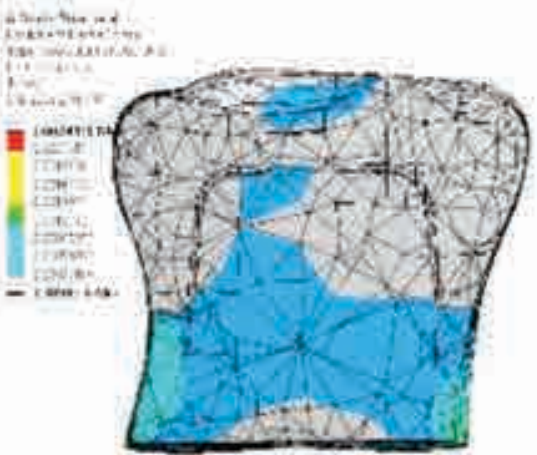

$30^{\circ}$

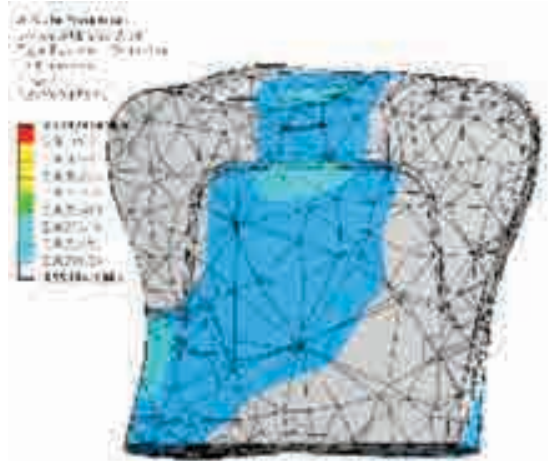

$75^{\circ}$



$45^{\circ}$

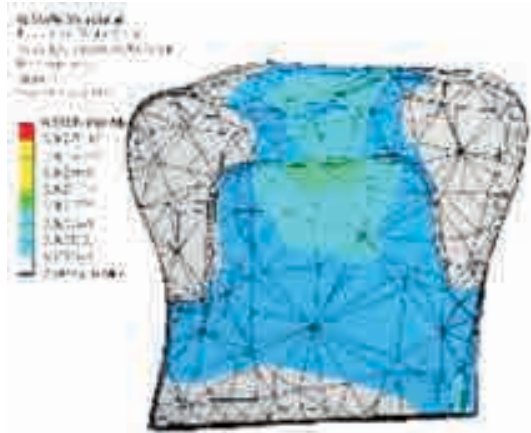

$90^{\circ}$

FIGURA 12. Deformația elastică echivalentă pentru solicitarea de $170 \mathrm{~N}$ şi orientările $0^{\circ}-90^{\circ}$ - secțiune longitudinală 




A

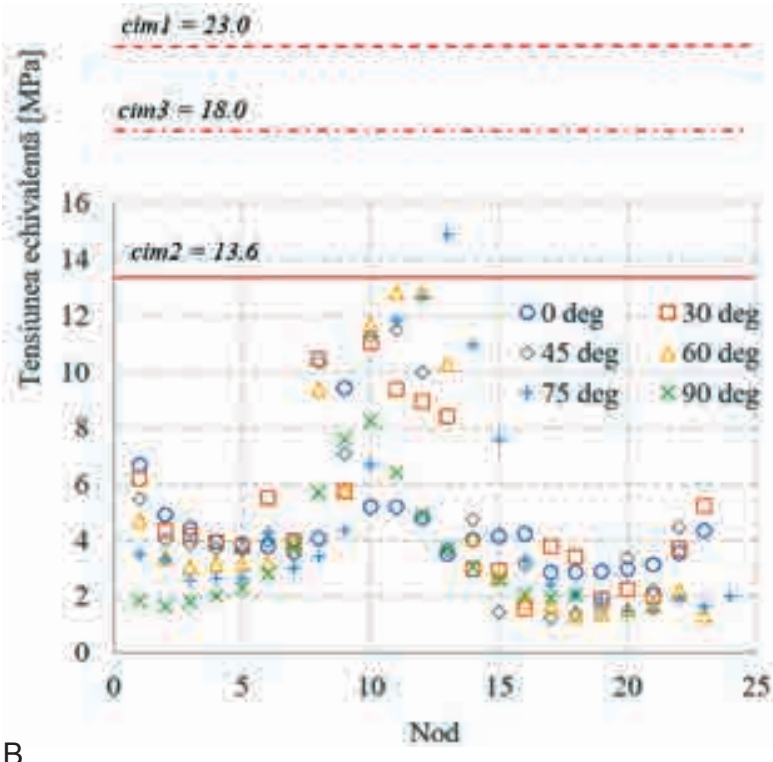

FIGURA 13. Rezistențele mecanice şi tensiunile echivalente obținute: A. în ceramică; B. în ciment

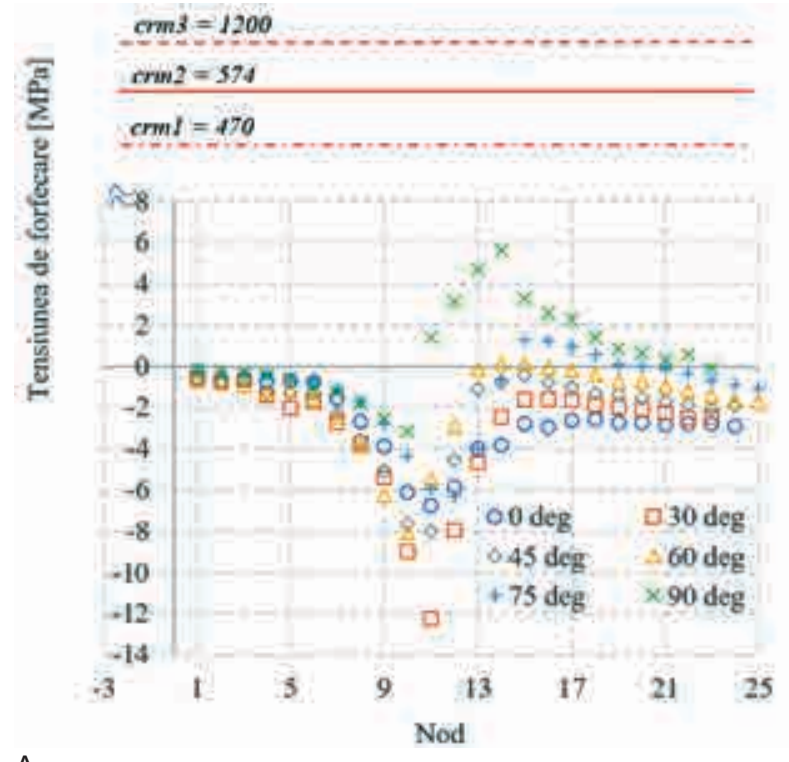

A

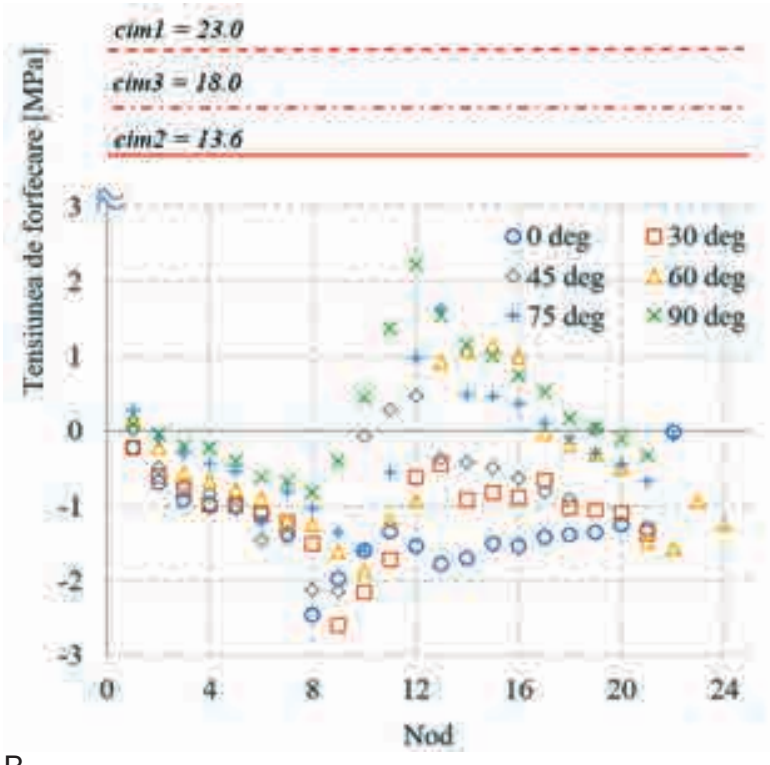

B

FIGURA 14. Rezistențele mecanice şi tensiunile de forfecare obținute: A. în ceramică; B. în ciment

Vârfurile de tensiune atât din coroană, cât și din ciment apar la nivelul pereţilor orizontali ai celor două elemente geometrice, urmând o coborâre bruscă spre valorile înregistrate pe pereţii verticali (fig. 13 și 14). Schimbarea de semn la nivelul tensiunilor de forfecare este normală şi se datorează schimbării de orientare a forţei aplicate în relaţie cu planul în care este studiată tensiunea (XY). Din acest motiv, compararea cu rezistenţele mecanice s-a realizat cu valorile luate în modul.

La compararea tensiunilor de forfecare cu rezistenţele admisibile ale materialelor din care sunt confecţionate componentele, trebuie luat în consi- derare şi faptul că schimbarea de semn a tensiunii la schimbarea orientării forţei înseamnă că, la o solicitare compusă, după mai multe direcţii, amplitudinea de tensiune vârf la vârf va avea valoare dublă. Dar oricum, nici pentru aceste valori extreme solicitarea nu depășește rezistenţele mecanice ale cimenturilor şi ceramicelor.

Tensiunile echivalente înregistrate la nivelul ceramicii sunt reduse, acest lucru datorându-se suprafeței portante mult mai mari a coroanei. În privinţa cimenturilor, tensiunile echivalente indică posibilă atingerea unor valori care pot conduce spre generarea de fisuri la interfaţă. 


\section{DISCUȚII}

Introducerea de noi generaţii de materiale ceramice în ultimul deceniu, precum și conceptul terapiei minimum invazive au indus o creștere a performanţei şi eficienţei restaurărilor indirecte dentare. Este, de asemenea, de semnalat că, în ultimii ani, s-a înregistrat o creștere mare a cererii pacienţilor pentru restaurări realizate din materiale fizionomice, prin urmare, atenţia cercetării ştiinţifice s-a concentrat pe astfel de materiale, în special pe disilicat de litiu şi zirconiu, pentru stabilirea proprietăţilor, indicaţiilor și limitelor acestor materiale.

Coroanele sunt una dintre cele mai frecvente opţiuni protetice pentru acoperirea şi protejarea dinţilor determinată de toleranţa mare la stres și la acţiunea forţelor masticatorii. Coroanele ceramice sunt structuri complexe ale căror rezistenţă și supravieţuire depind de mai mulţi factori, cum ar fi pregătirea dinţilor şi structura dentară reziduală după preparare, forma, grosimea, modulul de elasticitate al materialelor utilizate sau tehnica de fabricaţie. Disilicatul de litiu (E-max) şi zirconiul sunt unele dintre materialele utilizate pentru fabricarea coroanelor cu o calitate estetică şi proprietăţi mecanice ridicate.

Acest studiu se ocupă, prin intermediul elementului finit, de analiza valorilor de tensiune echivalentă și de forfecare, pe de-o parte, şi a deformărilor structurii, pe de altă parte, a unei coroane dentare, în conformitate $\mathrm{cu}$ materialele definite (ceramica disilicat de litiu presată şi monolitică, zirconia şi cimenturi autoadezive şi cu priză dublă) și cu direcţia solicitării aplicate. În simularea de faţă, s-a ales o singură valoare de solicitare de 170 $\mathrm{N}$, dar aplicată pe rând după 6 direcţii, $0^{\circ}, 30^{\circ}, 45^{\circ}$, $60^{\circ}, 75^{\circ}, 90^{\circ}$. În acest fel, sunt simulate în mod discret efectele de forfecare și până la compresiune pură a structurii.

Materialul restaurativ poate influenţa direct prognosticul pe termen lung al restaurărilor. În acest studiu, valorile de rezistenţă mecanică ale celor 3 materiale (crm1, crm2 și crm3) depășesc cu cel puțin un ordin de mărime valorile de tensiune echivalente sau de forfecare, ceea ce confirmă că o solicitare de valoare similară cu cea aplicată în simulare, orientată indiferent după ce direcție, nu poate produce efecte mecanice de fracturare a niciuneia dintre ceramici. Totodată, tensiunile echiva- lente înregistrate la nivelul ceramicii sunt reduse, acest lucru datorându-se suprafeţei portante mult mai mari a coroanei. De asemenea, secţiunile longitudinale ale ansamblului prezintă distribuţia de tensiune pe suprafeţe extinse şi în interiorul structurii. $\mathrm{Nu}$ apar zone preferenţiale spre un singur perete al molarului, ci, în aceeași măsură, simetric, tensiunea se transmite spre ambii pereţi (în planul studiat) și, desigur, şi pe ceilalţi corespunzători unui plan medial.

Fiecare material are o duritate specifică, care se reflectă în diferite module de elasticitate, permiţând diferite concentraţii de solicitări de tracţiune pe suprafaţa coroanei.

Tribst şi colab. au demonstrat că forţele de compresie maximă au fost concentrate ocluzal în centrul coroanei și forţa de tracţiune în suprafaţa demineralizată. Astfel, cu cât este mai mare modulul de elasticitate al materialului de restaurare, $\mathrm{cu}$ atât este mai mare concentraţia de solicitare la compresiune pe suprafaţa exterioară a restaurării ocluzale. Același comportament este observat și pentru concentraţia de tensiune la suprafaţa demineralizată: cu cât este mai mare modulul de elasticitate al materialului, cu atât este mai mare concentraţia de solicitare la întindere [23].

De asemenea, materialele restaurative cu modul de elasticitate mai ridicat prezintă o concentraţie de solicitare mai mare în interiorul coroanei, în principal forţa de tracţiune pe suprafaţa demineralizată. Pe de altă parte, materialele cu modul elastic mai mic cresc stresul de forfecare la ciment. Materialele mai rigide promovează valori de vârf ale stresului mai ridicate. Aceasta înseamnă clinic că zirconia permite o concentraţie mai mare de tensiune la suprafaţa coroanei şi o solicitare mai mare la stratul de ciment, facilitând decimentarea coroanei [24].

Comparând zirconiul cu ceramica şi ţinând cont că proprietatea de duritate constă în capacitatea materialului de a limita propagarea fisurilor, Tribst şi colab. susţin că vârfurile de stres din zirconiu nu au fost de două ori mai mari decât pentru ceramica disilicat de litiu [23].

De asemenea, rezistenţa la flexiune a zirconiului este de două ori mai mare decât cea a ceramicii disilicat de litiu [24].

Atunci când este susţinută de dentină, rezistenţa la fractură a restaurărilor de zirconiu este de aproximativ 1,8 ori mai mare decât ceramica disilicat 
de litiu, iar când este susţinută de smalţ, rezistenţa la fractură a zirconiului este de 1,3-1,4 ori mai mare decât disilicatul de litiu. Acest lucru este valabil pentru o grosime de restaurare a ceramicii de 0,6-1,4 mm, sugerând că disilicatul de litiu este adecvat în special pentru utilizare în restaurări conservatoare în care preparatul poate fi limitat la smalţ [25].

Prognosticul pe termen lung al unei restaurări adezive nu este influenţat doar de calităţile materialului restaurator, ci şi de materialele folosite pentru cimentare, precum şi de pregătirea adecvată a suprafeţelor implicate în adeziune/cimentarea adezivă. Semnificaţia pregătirii corecte a suprafețelor implicate în adeziune este tradusă clinic prin evitarea decimentării restaurărilor care se poate datora slăbirii adeziunii dintre interfeţele ciment/structură dentară, ciment/ceramică sau fracturilor din ciment. Astfel, pentru o bună rezistenţă adezivă, un rol important îl joacă modul de pregătire a suprafeței interne a coroanei, demineralizarea cu acid fluorhidric asigurând cea mai mare rezistenţă [26].

În acest studiu, valorile reduse ale tensiunilor echivalente înregistrate la nivelul ceramicii pot fi considerate o consecinţă a pregătirii adecvate a suprafețelor interne ale coroanelor.

Importanţa materialului folosit la cimentare, precum şi tipul preparaţiei dentare pot influenţa răspunsul coroanei la acţiunea forţelor de încărcare. Acest lucru este discutat de Galal şi colab., care au analizat, cu ajutorul metodei elementului finit, comportamentul unei restaurări coronare molare din E max, cimentată fie cu RelyX, fie cu ionomer de sticlă, şi au concluzionat că modul de preparare a dintelui are aceeași importanţă în inducerea răspunsului la acţiunea forţelor de încărcare ca şi ceramica şi cimentul adeziv utilizate. Mai mult, cimentul RelyX a împărţit absorbţia energiei de încărcare cu coroana E-max mai bine decât cimentul ionomer de sticlă. Coroana E-max cimentată cu RelyX și unghi de pregătire dentară de $18^{\circ}$ este mai rezistentă decât aceeași combinaţie, dar cu unghiul de pregătire de $10^{\circ}$ [27].

Referitor la cimenturile adezive utilizate în acest studiu MEF, rezultatele arată că tensiunile echivalente indică o posibilă atingere a unor valori care pot conduce spre generarea de fisuri la interfaţă. Astfel, indicaţia cimenturilor devine foarte importantă.
Ha SR şi colab., în studiul lor, au evidenţiat concentraţii mai mari de stres pe suprafețele ocluzale la coroanele de zirconiu monolitice, în timp ce straturile de ciment au mai multe concentraţii de stres pe zonele cervicale [28].

Luând în calcul proprietăţile fizico-chimice ale zirconiului, preparaţiile retentive și restaurările de acoperire totală pot beneficia de agenţi convenţionali adezivi pe bază de apă şi cimenturi hibride pentru o bună cimentare. Cimenturile de tipul celor autoadezive ar trebui utilizate în restaurări de acoperire parţială a coroanelor neretentive şi a forţelor de masticaţie ridicate; astfel, se vor evita posibilele microfisuri de pe suprafaţa interioară a restaurărilor [29].

Totuşi, studiul realizat de Nakamura şi colab. [30], privind efectul cimentului asupra rezistenţei mecanice a coroanelor monolitice din zirconiu, a prezentat faptul că şi coroanele cu o grosime minimă de 0,5 mm pot avea o bună rezistenţă la fractură în ciuda oricărui ciment utilizat.

Tot Nakamura și colab. [30] au constatat că rezistenţa la compresiune a cimenturilor adezive, de tip cimenturi autoadezive sau cu priză dublă, a fost mai mare decât a fosfatului de zinc şi cimentul ionomer de sticlă, fără însă a fi afectată rezistenţa la rupere a coroanelor cimentate de acestea.

$\mathrm{Au}$ fost publicate mai multe studii care au măsurat rezistenţa la forfecare a diferitelor cimenturi. Deformarea unei coroane cimentate se produce ca urmare a tensiunii induse în interiorul ei de acţiunea forţelor. Analiza prin MEF este capabilă să evidenţieze harta de prevalenţa a stresului la nivelul dintelui şi restaurării.

Waly şi colab. au studiat cu MEF rezistenţa la forţele de masticaţie a unor cimenturi diferite după aplicarea unei forţe de $330 \mathrm{~N}$ cu trei direcţii, vertical, oblic la $45^{\circ}$ și lateral, şi au recomandat utilizarea cimenturilor cu duritate crescută pentru a susţine şi a reduce tensiunile şi deformările. Tensiunea din interiorul coroanei a crescut prin reducerea rigidităţii cimentului folosit, în timp ce tensiunile asupra structurii dintelui au fost diminuate prin scăderea rigidităţii cimentului. Creșterea unghiului de înclinare a sarcinii a redus diferenţa de solicitare la nivelul coroanei între diferitele tipuri de ciment, în timp ce, la nivelul dintelui, efectul este opus [31].

În acest studiu, am folosit pentru cimentarea coroanelor de ceramică trei tipuri de ciment, autoadeziv, universal şi cu priză dublă. Deformaţiile 
semnificative ale structurii s-au produs la nivelul cimentului adeziv şi dentinei (fig. 11 și 12). În conformitate cu direcţia solicitării, pereţii molarului se vor deforma în mod egal la solicitări de compresiune $\left(90^{\circ}\right)$ și nesimetric pentru solicitări oblice. $\mathrm{Nu}$ se constată deformaţii elastice semnificative ca urmare a rigidităţii mari a coroanei.

Ha SR şi colab. au evaluat, utilizând MEF, influenţa diferitelor tipuri de ciment (fosfat de zinc, policarboxilat, ionomer de sticlă și rășină) asupra distribuţiei stresului în coroanele monolitice de zirconiu pe care s-a aplicat vertical o forţă de 700 N pe 8 puncte de încărcare. Rezultatele obţinute de ei indică faptul că utilizarea diferiţilor agenţi de adezivi, care au module de elasticitate diferite, are impact asupra distribuţiei tensiunilor la nivelul coroanelor de zirconiu monolitice, straturilor de ciment şi dintelui. Cimentul de răşină şi cimentul ionomer de sticlă au prezentat modele similare, dar cimentul de rășină a prezentat o distribuţie mai mică a tensiunii pe suprafaţa linguală și mezială a stratului de ciment [28].

În acest studiu se observă că cimentul $\operatorname{cim} 3$ (Variolink) are limita de rezistenţă mecanică foarte apropiată de valorile de tensiune obţinute în punctele critice ale structurilor. Acest lucru ar putea determina în practică o fracturare a acestui ciment, în special la aplicarea oblică sau tangentă a solicitării pe molar.

Acelaşi rezultat a fost obţinut și de analiza mecanismului de decimentare a unor restaurări din zirconiu şi disilicat de litiu cimentate la dentină cu cimenturi adezive diferite (Variolink Esthetic şi RelyX Unicem) cu priză dublă - și anume că fractura între ciment și dentină şi fractura în dentină au fost observate pentru Variolink Esthetic şi RelyX Unicem. Numărul mare de fracturi din ciment a sugerat că cimentul a fost cea mai slabă verigă în sis-

\section{BIBLIOGRAFIE}

1. Narasimha Raghavan R. Ceramics in Dentistry. In: Arunachalam Lakshmanan, Sintering of Ceramics - New Emerging Technique. InTech. 2012:203-207.

2. Oh WS, Shen C. Effect of surface topography on the bond strength of a composite to three different types of ceramic. J Prosthet Dent. 2003;90(3):241-6.

3. Zarone F, Ferrari M, Mangano FG, Leone R, Sorrentino R. "Digitally oriented materials": focus on lithium disilicate ceramics. Int J Dent. 2016;1-7.

4. Chen YW, Moussi J, Drury JL, Wataha JC. Zirconia in biomedical applications. Expert Rev Med Devices. 2016;13(10):945-63. temul adeziv coroană disilicat de litiu/zirconiu/ dentină [32].

\section{CONCLUZII}

Valorile de rezistenţă mecanică ale celor 3 ceramice (crm1, crm2 şi crm3) depăşesc cu cel puţin un ordin de mărime valorile de tensiune echivalente sau de forfecare, ceea ce confirmă că o solicitare de valoare similară cu cea aplicată în simulare, orientată indiferent după ce direcţie, nu poate produce efecte mecanice de fracturare a niciuneia dintre ceramici.

Valorile de rezistenţă mecanică la adeziune ale cimenturilor fiind mult mai reduse decât valorile de rezistenţă ale ceramicelor, efectul produs de solicitare va fi unul diferit. Se observă preponderent că cimentul cim3 (Variolink) are limita de rezistenţă mecanică foarte apropiată de valorile de tensiune obţinute în punctele critice ale structurilor. Acest lucru ar putea determina în practică o fracturare a cimentului cim3, în special la aplicarea oblică sau tangentă a solicitării pe molar.

Tensiunile echivalente înregistrate la nivelul ceramicii sunt reduse, acest lucru datorându-se suprafeței portante mari a coroanei. Acest lucru face ca o coroană să fie mult mai puţin susceptibilă la fracturare comparativ cu alte tipuri de restaurări (inlay, onlay).

Tensiunile echivalente din cimentul adeziv indică o posibilă atingerea unor valori care pot conduce spre generarea temperata de fisuri la interfaţă.

\section{Notă}

Articolul face parte din teza de doctorat a Drd. Otilia Chirca, coordonator știinţific: Prof. Dr. Cornelia Bîcleşanu, Școala doctorală Facultatea de Medicină dentară, Universitatea „Titu Maiorescu“, București.

Conflict of interest: none declared Financial support: none declared

5. Bishara SE, Ostby AW, Ajlouni R, Laffoon JF, Warren JJ. Earlyshear bond strength of a one-step self-adhesive on orthodontic brackets. Angle Orthod. 2006;76:689-693.

6. Kachhara S, Ariga P. Jain AR. Recommended cementation for monolithic zirconia crowns. Drug Invention Today 2018;10:566-568.

7. Goracci C, Cury AH, Cantoro A, Papacchini F, Tay FR, Ferrari M. Microtensile bond strength and interfacial properties of self-etching and self-adhesive resin cements used to lute composite onlays under different seating forces. J Adhes Dent. 2006;8:327-335.

8. Abo-Hamar SE, Hiller KA, Jung H, Federlin M, Friedl KH, Schmalz $\mathrm{G}$. Bond strength of a new universal self-adhesive 
resinluting cement to dentin and enamel. Clin Oral Investig. 2005; 9:161-167.

9. Taguchi S, Komine F, Kubochi K, Fushiki R, Kimura F, Matsumura H. Effect of a silane and phosphate functional monomer on shear bond strength of a resin-based luting agent to lithium disilicate ceramic and quartz materials. J Oral Sci. 2018;60(3):360-6.

10. Dawod N, Florescu A, Antoniac IV, Stoia DI, Hancu V, Biclesanu FC. The FEA Study of the Biomecanic Behavior of Canine Reconstructed with Composite Resin. Rev Chim. 2019; 70(7):2456-2462.

11. Antoniac IV, Stoia DI, Ghiban B, Tecu C, Miculescu F, Vigaru C, Saceleanu V. Failure analysis of a Humeral Shaft Locking Compression Plate (LCP) - Surface Investigations and FEM Simulations. MDPI - Materials 2019;12(6):1128.

12. Marinescu R, Antoniac VI, Stoia DI, Liptoiu DC. Clavicle anatomical osteosynthesis plate breakage - failure analysis report based on patient morphological parameters. Romanian Journal of Morphology and Embryology 2017;58(2):593-598.

13. Toth-Tascau M, Stoia DI. Modeling and Numerical Analysis of a Cervical Spine Unit.I In: Antoniac I, Biologically Responsive Biomaterials for Tissue Engineering, Ed. Springer, 2012:137-171.

14. Kandziora F, Ludwig K. Biomechanical assessment of four different anterior atlantoaxial plates. North American Spine Society 15th Annual Meeting, 2000.

15. Brinckmann P, Frobin W, Gunnar WE. Musculoskeletal Biomechanics, Stuttgart - New York: Thieme, 2000.

16. Drăgulescu D. Modelarea în biomecanică. Bucureşti: Editura Didactică şi Pedagogică, 2005.

17. Trindade FZ, Valandro LF, de Jager N, Bottino MA, Kleverlaan CJ. Elastic Properties of Lithium Disilicate Versus Feldspathic Inlays: Effect on the Bonding by 3D Finite Element Analysis. J Prosthodont. 2018;27(8):741-747.

18. Furuichi T, Takamizawa T, Tsujimoto A, Miyazaki M, Barkmeier WW, Latta MA. Mechanical Properties and Sliding-impact Wear Resistance of Self-adhesive Resin Cements. Operative Dentistry 2016;41(3):E83-E92.

19. Walls AWG, Lee J, McCabe JF. The bonding of composite resin to moist enamel. British Dental Journal 2001;191(3):148-50.

20. Kimmes NS, Barkmeier WW, Erickson RL, Latta MA. Adhesive bond strengths to enamel and dentin using recommended and extended treatment times. Oper Dent. 2010;35(1):112-9.
21. Malek S, Darendeliler MA, Swain MV. Physical properties of root cementum: Part I. A new method for 3-dimensional evaluation. Am J Orthod Dentofacial Orthop. 2001;120(2):198-208.

22. Sarr M, Leye-Benoist F, Aidara AW, Faye B, Bane K, Touré B. Characterization of the Resin Luting Materials: Percentage, Morphology and Mechanical Properties. Journal of Dentistry and Oral Care Medicine, 2016;2(3):1-7.

23. Tribst JPM, Dal Piva AMO, Penteado MM, Borges ALS, Bottino MA. Influence of ceramic material, thickness of restoration and cement layer on stress distribution of occlusal veneers. Braz Oral Res. 2018;32:e118.

24. Dal Piva AMO, Tribst JPM, Borges ALS, Souza ROAE, Bottino MA. CAD-FEA modeling and analysis of different full crown monolithic restorations. Dent Mater. 2018;34(9):1342-50.

25. Ma L, Guess PC, Zhang Y. Load-bearing properties of minimalinvasive monolithic lithium disilicate and zirconia occlusal onlays: Finite element and theoretical analyses. Dental Materials 2013; 29:742-751.

26. Kvam K, Irkayek A, Vangaeva E, El-Homsi F. Comparison of sandblasted, ground and melt-etched zirconia crowns regarding adhesion strength to resin cement. Biomater Investig Dent. 2019; 6(1):1-5.

27. Galal RM, Yossef SA, Alsairafi MA, Alkhashem TM. A finite element study on effect of cement type and preparation angle on mandibular molar crown restorations' stresses. J Int Oral Health. 2018;10:143-7.

28. Ha SR et al. Biomechanical three-dimensional finite element analysis of monolithic zirconia crown with different cement thickness. Ceramics International 2016;42:14928-14936.

29. Zarone F, Di Mauro MI, Ausiello P et al. Current status on lithium disilicate and zirconia: a narrative review. BMC Oral Health. 2019; 19:134.

30. Nakamura K, Mouhat M, Nergård JM, Lægreid SJ, Kanno T, Milleding $\mathrm{P}$, et al. Effect of cements on fracture resistance of monolithic zirconia crowns. Acta Biomater Odontol Scand. 2016; 2:12-9.

31. Waly AS, Souror YR, Yousief SA, Alqahtani WMS, El-Anwar MI. Pediatric Stainless-Steel Crown Cementation Finite Element Study. Eur J Dent. 2020.

32. Sagen MA, Kvam K, Ruyter El, Rønold HJ. Debonding mechanism of zirconia and lithium disilicate resin cemented to dentin. Acta Biomater Odontol Scand. 2019;5(1):22-29. 